\title{
IMPACT OF PB, NI AND CD ON THE GERMINATION OF BARLEY SEEDS, VARIETY JADRAN
}

\author{
PREDRAG VASIĆ ${ }^{1}$, TATJANA JAKŠIĆ ${ }^{1}$, GORICA ĐELIĆ \\ ${ }^{1}$ Faculty of Sciences, University in Priština - Kosovska Mitrovica, Kosovska Mitrovica, Serbia \\ ${ }^{2}$ Department of Biology and Ecology, Faculty of Science, University of Kragujevac, Kragujevac, Serbia
}

\begin{abstract}
The aim of this study was to determine the effect of lead, nickel and cadmium on the germination of barley seeds (Hordeum vulgare L.) of Jadran variety. Based on the percentage of germination, germination energy, and root and hypocotyl length, authors done an analysis of the effects of $\mathrm{PbCl}_{2}, \mathrm{NiCl}_{2}, \mathrm{CdCl}_{2}$ solutions, in concentrations of $10^{3} \mathrm{~mol} / \mathrm{m}^{3}, 10^{2} \mathrm{~mol} / \mathrm{m}^{3}, 10 \mathrm{~mol} / \mathrm{m}^{3}, 1 \mathrm{~mol} / \mathrm{m}^{3}, 10^{-1} \mathrm{~mol} / \mathrm{m}^{3}, 10^{-2} \mathrm{~mol} / \mathrm{m}^{3}$. The results showed that germination and germgrowthin stress conditions which are caused by heavy metals depend on the type of metal and its concentrations. The most toxic effect of allested solutions had $\mathrm{CdCl}_{2}$, and the weakest toxic effect had $\mathrm{PbCl}_{2}$.
\end{abstract}

\section{Keywords: Hordeum vulgare L., Lead, Nickel, Cadmium, Germination.}

\section{INTRODUCTION}

The harmful effects of heavy metals in soil are reflected in the entire ecosystem (Kabata-Pendias, 2011). By accumulation in soil, heavy metals are involved in biochemical processes of element circulation, and in food chains. As a consequence of an inadequate application of chemicals, artificial fertilizers, etc. in agriculture, an increased amount of heavy metals occurs in agricultural land, which leads to the manifestation of their phytotoxic and negative impact on the quality of plant products (Rajkovic et al., 2012., Djelic et al., 2012., Pesko et al., 2011). Plants that grow or which are cultivated on contaminated land present health hazard for animals and human population.

Maximum permitted levels (MPL) of hazardous and noxious substances in soil and irrigation water, which can damage or alter the agricultural production capacity and the quality of irrigation water, coming from discharges from factories, dumping, improper use of mineral fertilizers and preservatives plants, are regulated in the Republic of Serbia by the Rulebook on the allowed quantities of dangerous and harmful substances in soil and water for irrigation and methods of their testing. If land contains more than the maximum allowed levels (Tab.1), than it is not recommended for agricultural production. Barley is considered to be one of the oldest, most widespread cereal in Europe. It has been cultivated for over 10,000 years (Salamini et al., 2002).

The species of the genus Hordeum have a basic number of chromosomes 7. Grown barley Hordeum vulgare L. ssp. vulgare and its wild ancestor H. vulgare L. ssp. spontaneum (C. Koch.) Thell. are diploid species with $2 \mathrm{n}=14$ chromosomes.

All cultivated forms of barley belong to species Hordeum vulgare L., which is divided into three subspecies based on the number of developed classics (Kricka et al., 2012): double row

\footnotetext{
* Corresponding author: gorica.djelic@ pmf.kg.ac.rs

barley (H. vulgare ssp. distichum), transitional barley (H. vulgare ssp. intermedium), row barley (H. vulgare ssp. polystichum).

It has short vegetation, and it istolerantto low temperatures, drought, salts, and basic soil reaction (Poehlman et al., 1985).

In order to obtain higher yields and better grain quality, numerous tests are being carried out to create new varieties resistant to biotic and abiotic stress (Zhang et al., 2001). So far, 124 varieties of barley have been created in the Republic of Serbia (Madic et al., 2011).

Barley (H. vulgare) is the most widespread of all cereal. It has a very rich nutritional value because it contains a large amount of vitamin B complex, and vitamins A, E, K, D. It is an excellent source of vegetable fibers, proteins, phosphorus, magnesium, zinc, iron, etc. Only $200 \mathrm{~g}$ of barley contain $55 \%$ of the recommended daily amount of vegetable fiber. It is gluten free and easy to digest, and due to its medicinal properties it is recommended that people consume this valuable food frequently (Tanner et al., 2016).

Table 1. Maximum permitted levels.

\begin{tabular}{|c|c|c|}
\hline $\begin{array}{c}\text { Chemical } \\
\text { elements }\end{array}$ & $\begin{array}{c}\text { Maximum } \\
\text { permitted levels } \\
\text { in soil } \\
\mathrm{mg} / \mathrm{kg} \text { soil }\end{array}$ & $\begin{array}{c}\text { Maximum } \\
\text { permitted levels } \\
\text { in water } \\
\mathrm{mg} / \mathrm{lwater}\end{array}$ \\
\hline Cadmium & to 3 & to 0.01 \\
\hline Lead & to 100 & to 0.1 \\
\hline Nickel & to 50 & to 0.1 \\
\hline
\end{tabular}

The Jadran variety is spring barley which is cultivated during summer time. It is characterized by a low stalk and good resistance to lodging. The quality of the grain and malt is excellent. The aim of this study was to determine the effect of different concentrations of heavy metals $\mathrm{Pb}, \mathrm{Ni}, \mathrm{Cd}$ on the germination, germination energy, root length and hypocotyl of barley (H.vulgare) seeds of the Jadran cultivar. 


\section{EXPERIMENTAL}

\section{Materials and methods}

The toxic effect of heavy metals on barley seeds of Jadran cultivar was investigated using a solutions of $\mathrm{PbCl}_{2}, \mathrm{NiCl}_{2}$, $\mathrm{CdCl}_{2}$, prepared in distilled water,in 7 different concentrations as follows: $10^{3} \mathrm{~mol} / \mathrm{m}^{3}, 10^{2} \mathrm{~mol} / \mathrm{m}^{3}, 10 \mathrm{~mol} / \mathrm{m}^{3}, 1 \mathrm{~mol} / \mathrm{m}^{3}, 10^{-1}$ $\mathrm{mol} / \mathrm{m}^{3}, 10^{-2} \mathrm{~mol} / \mathrm{m}^{3}$ and $0 \mathrm{~mol} / \mathrm{m}^{3}$ (control)

100 seeds were planted for each concentration. 7 petri boxes were used on the bottom of which the filter paper was loaded with: 7 different concentrations of each heavy metal. Petri boxes with seeds were placed in a thermostat at a temperature of $+22^{\circ} \mathrm{C}$. The experiment was done in three repetitions.

The length of the root, hypocotyl, was determined on the fifth day after placement of the experiment.

Germination energy was calculated by the form:

$$
\frac{\sum(n x p)}{\sum m}
$$

where: $\mathrm{n}$ - germination time (first day, second day...); $\mathrm{p}$ number of germinated seeds; $\mathrm{m}$ - total number of germinating seeds (Komljenović \& Todorović, 1998).

The analyzed parameters are shown in the mean values and were statistically processed by the method of analysis of variance using two-factor trial, and the significance of differences was tested by LSD test for P 0.05 and 0.01 .For statistically process the results it was used SPSS Statistics program (SPSS 16 for Windows).

\section{RESULTS AND DISCUSSIONS}

The percentage of germination of spring barley (H. vulgare) seeds of the Jadran variety in distilled water (control) is $85 \%$ (Fig. 1). Increase of heavy metal concentrations significantly decreased the germination percentage of barley.

Lead content in soil is very variable. This variability is mainly caused by the parent substrate on which the soil was formed. It is even more absorbed than $\mathrm{Cu}, \mathrm{Zn}, \mathrm{Cd}$, which behave similarly in soil as lead (Steiger, 1996). The $\mathrm{pH}$ reaction of the soil significantly affects the bioavailability of $\mathrm{Pb}$, because increased acidity of soilincreases $\mathrm{Pb}$ solubitily. However, this process is relatively slow (KabataPendias, 2011). Usually $\mathrm{Pb}$ in soil is highly adsorbed to soil particles and it creates precipitates in high degree. Only about $0.005-0.13 \% \mathrm{~Pb}$ in soil solution is available to plants (Kabata-Pendias, 2011).

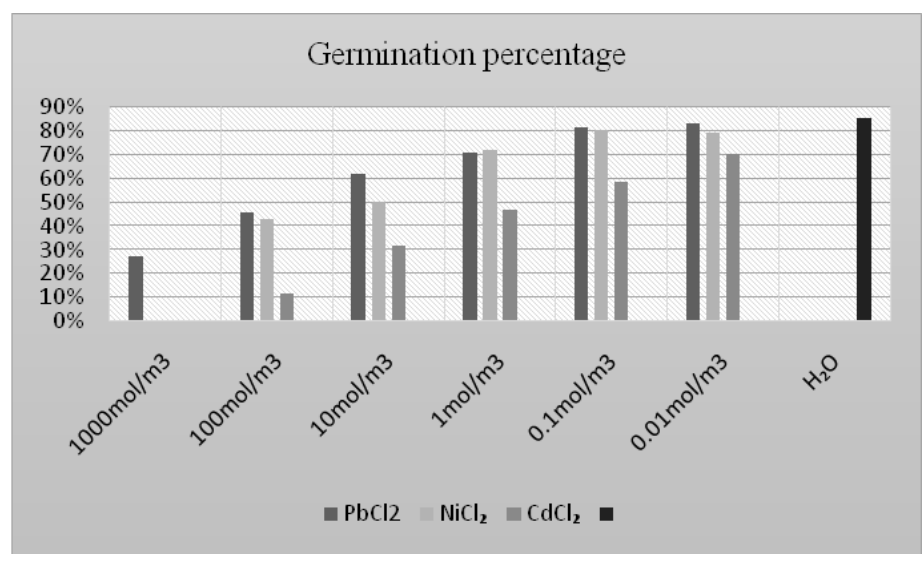

Figure 1. The germination percentage of barley seeds (Hordeum vulgare L. varieties Jadran) in solutions of different concentrations of $\mathrm{PbCl}_{2}, \mathrm{NiCl}_{2}, \mathrm{CdCl}_{2}$

Research results from Azmat et al. (2006) show that lead inhibits germination of seeds, decreases germination percentage, germination index, and root/hypocotyl length in Phaseolus mungo and Lens culinaris species.

Our research (Tab. 2) shows that the $\mathrm{PbCl}_{2}$ solution has the highest toxicity to germination of the seeds of spring barley $(H$. vulgare) of the Jadran variety at a concentration of $10^{3} \mathrm{~mol} / \mathrm{m}^{3}$ where germination is reduced by $58 \%$ in relation to control. At the lowest concentration of $10^{-2} \mathrm{~mol} / \mathrm{m}^{3}$ seed germination was reduced by $2 \%$ compared to the control.

Table 2. The percentage of germination of barley seeds (Hordeum vulgare L. varieties Jadran) in solutions of different concentrations of $\mathrm{PbCl}_{2}, \mathrm{NiCl}_{2}, \mathrm{CdCl}_{2}$.

\begin{tabular}{|c|c|c|c|c|c|c|}
\hline & $\mathbf{1 0}^{\mathbf{3}} \mathbf{m o l} / \mathbf{m}^{\mathbf{3}}$ & $\mathbf{1 0}^{\mathbf{2}} \mathbf{m o l} / \mathbf{m}^{\mathbf{3}}$ & $\mathbf{1 0 \mathbf { m o l }} / \mathbf{m}^{\mathbf{3}}$ & $\mathbf{1} \mathbf{m o l} / \mathbf{m}^{\mathbf{3}}$ & $10^{-1} \mathbf{m o l} / \mathbf{m}^{\mathbf{3}}$ & $10^{-2} \mathbf{m o l} / \mathbf{m}^{\mathbf{3}}$ \\
\hline $\mathrm{PbCl}_{2}$ & $27 \%$ & $45.5 \%$ & $61.5 \%$ & $70.5 \%$ & $81 \%$ & $83 \%$ \\
\hline $\mathrm{NiCl}_{2}$ & $0 \%$ & $42.5 \%$ & $50 \%$ & $71.6 \%$ & $80 \%$ & $79 \%$ \\
\hline $\mathrm{CdCl}_{2}$ & $0 \%$ & $11.5 \%$ & $31.5 \%$ & $46.6 \%$ & $58.3 \%$ & $70 \%$ \\
\hline $\mathrm{H}_{2} \mathrm{O}$ & $85 \%$ & & & & & \\
\hline
\end{tabular}

Nickel is an essential element required for plant growth and iron resorption (Chen et al., 2009). It is part of the urease enzyme that hydrolyzes urea in plant tissues (Polacco et al., 2013). The main mechanisms by which plants take up Ni are passive diffusion and active transport (Ahmad \& Ashraf 2011). Excess Ni affects the absorption of nutrients at the root, decreases plant metabolism, inhibits photosynthesis and transpiration, causes ultrastructural modifications and oxidative stress (Chen et al., 2009). Nickel disrupts the Krebs cycle and electron transport in the process of oxidative phosphorylation.

Nickel, unlike lead, has good motility in both xylem and phloem and in large quantities is accumulated in fruits and seeds. Leaves usually have the highest nickel content, the younger parts have a higher content than the older ones, and the seeds have a 
higher content than the straw..Nickel adversely affects not only the mobility or translocation of iron, but also its uptake.

Leone et al. (2005) indicate that the strongest toxic effect on seed germination has $\mathrm{Ni}$ in the form of $\mathrm{NiCl}_{2}$, and weaker as $\mathrm{Ni}$ sulfate and $\mathrm{Ni}$ acetate.

The results of this studyshow that seeds of $H$. vulgare Jadran varieties did not germinate in $\mathrm{NiCl}_{2}$ solution, with concentrations of $10^{3} \mathrm{~mol} / \mathrm{m}^{3}$ (Fig.1), so this concentration is lethal to seeds of this species. The sublethal concentration is $10^{2}$ $\mathrm{mol} / \mathrm{m}^{3}$ because it is the concentration in which $11.5 \%$ seeds germinate, which is $74 \%$ less than the control. $\mathrm{NiCl}_{2}$ solution in concentrations from $10 \mathrm{~mol} / \mathrm{m}^{3}$ to $10^{-2} \mathrm{~mol} / \mathrm{m}^{3}$ reduces the germination rate by up to $7 \%$ compared to the control (Tab. 1).

$\mathrm{Cd}$ is not an essential element for plants, but they adopt it (Porębska \& Ostrowska, 1999). Cadmium absorbed from the nutrient medium is generally retained in the root. High concentrations of cadmium in plants inhibit respiration and electron transport in the process of oxidative phosphorylation, inhibit metabolism due to interactions with zinc, induce chlorosis and thus reduce the intensity of photosynthesis. The toxic effect of cadmium on plants has been the subject of numerous studies (Djelic et al., 2016, 2018; Ahmad et al., 2015; Shafi et al., 2010; Stankovic et al., 2010; Khan et al., 2006; Peralta-Videa et al., 2002; Jiang et al., 2001). The obtained results show that the germination of seeds of barley, Jadran variety, in the weakest $\mathrm{Cd}$ concentration is $15 \%$ less in comparison with the control, $13 \%$ less in comparison with the solution of the same $\mathrm{Ni}$ concentration and $9 \%$ less in comparison with the $\mathrm{Pb}$ solution. With increasing concentration of $\mathrm{CdCl}_{2}$ solution, the germination percentage decreases drastically (Tab. 2). The lethal concentration is $10^{3}$ $\mathrm{mol} / \mathrm{m}^{3}$.

Based on the toxic effect on the $\%$ germinated seeds of barley ( $H$. vulgare.), Jadran variety, we can compare the following: $\mathrm{Cd}>\mathrm{Ni}>\mathrm{Pb}$.

The average root length on tested seeds of barley $(H$. vulgare) Jadran variety, in water (control) is $76.3 \mathrm{~mm}$ (Xmin - 18 $\mathrm{mm}, \mathrm{Xmax}-132 \mathrm{~mm})$, and the mean hypocotyl length is 71.2 mm (Xmin - 19 mm, Xmax - 135 mm).

The lead solution exhibited the least toxic effect (Tab. 3) of all tested metals, on root and hypocotyl growth. The toxicity of $\mathrm{PbCl}_{2}$ solution was more pronounced on root and hypocotyl length than of $\%$ germinated seeds. At a concentration of $10^{3}$ $\mathrm{mol} / \mathrm{m}^{3}$, the root length is $3.1 \mathrm{~mm}$, which is $73.2 \mathrm{~mm}$, is $95,8 \%$ shorter than the control and the germination rate at this concentration is reduced by $58 \%$. At a concentration of $10^{2}$ $\mathrm{mol} / \mathrm{m}^{3}$ the root length was $70.7 \mathrm{~mm}$ shorter than the control (Tab. 2), and the hypocotyl length $61 \mathrm{~mm}$ shorter than the control. Root length in solution of $10 \mathrm{~mol} / \mathrm{m}^{3}$ is $33.1 \mathrm{~mm}$ (43.4\%), concentration of $1 \mathrm{~mol} / \mathrm{m}^{3}$ is $31 \mathrm{~mm}(40.6 \%)$, concentrations are $10^{-1} \mathrm{~mol} / \mathrm{m}^{3}$ by $23.1 \mathrm{~mm}(30.3 \%)$, concentrations are $10^{-2} \mathrm{~mol} / \mathrm{m}^{3}$ is $22.3 \mathrm{~mm}(29.26 \%)$ smaller than in control. In all $\mathrm{PbCl}_{2}$ tested solutions, there was a significant shortening of hypocotyl length (Tab. 4) relative to the control.

$\mathrm{NiCl}_{2}$ has a stronger toxic effect on root growth and hypocotyl of barley germ than $\mathrm{PbCl}_{2}$. A high level of toxicity can also be observed at a concentration of $10^{2} \mathrm{~mol} / \mathrm{m}^{3}$ since the measured root length at this concentration is only $2.3 \mathrm{~mm}$, which is $74 \mathrm{~mm}(97 \%)$ less than the control. The length of the hypocotyl at this concentration is also small $(1,6 \mathrm{~mm})$. The solution in concentration of $10 \mathrm{~mol} / \mathrm{m}^{3}$ has slightly weaker toxic effect where the root length is $7.9 \mathrm{~mm}$ which is $68.4 \mathrm{~mm}$ shorter than the control (Tab. 1) and the length of the hypocotyl is 38.6 $\mathrm{mm}$ which is $37.7 \mathrm{~mm}$ shorter than the control. If we compare with the values in the solution of $\mathrm{PbCl}_{2}$ in concentration of 10 $\mathrm{mol} / \mathrm{m}^{3}$, we will notice that the root length in the nickel solution is shorter by $35.3 \mathrm{~mm}$ and the hypocotyls by $33.2 \mathrm{~mm}$ shorter than the values measured in the lead solution.

This result indicates a stronger toxic effect of nickel than lead. The root and hypocotyl lengths at a concentration of $1 \mathrm{~mol} / \mathrm{m}_{3}$ are $38.6 \mathrm{~mm}$ and $52.7 \mathrm{~mm}$, which is $38 \mathrm{~mm}$ and 23.9 $\mathrm{mm}$ less than the control. and at this concentration $\mathrm{NiCl}_{2}$ has a stronger toxic effect than $\mathrm{PbCl}_{2}$. Concentrations of $10^{-1} \mathrm{~mol} / \mathrm{m}^{3}$ and $10^{-2} \mathrm{~mol} / \mathrm{m}^{3}$ have the least toxic effect, but they also significantly reduce root length and hypocotyl.

The root length of the germ of barley ( $H$. vulgare.), Jadran variety, at all concentrations of $\mathrm{CdCl}_{2}$ solution is shorter than that in control. In the solution of concentration $10^{2} \mathrm{~mol} / \mathrm{m}^{3}$, the root was shorter by $98.8 \%$ compared to the control, compared to $\mathrm{PbCl}_{2}$ by $4.6 \mathrm{~mm}$ and $82.1 \%$, respectively, and by $1.3 \mathrm{~mm}$ and $56.2 \%$ shorter than $\mathrm{NiCl}_{2}$. A significant decrease in root growth was also observed in the solution of concentration of $10 \mathrm{~mol} / \mathrm{m}^{3}$, where the root length is $3.4 \mathrm{~mm}$, which is $42.9 \mathrm{~mm}$ shorter than the control and $39,8 \mathrm{~mm}$ shorter than rootsin $\mathrm{PbCl}_{2}$ solution. A significant decrease in the root length of the germ of barley, Jadran variety, was also observed in solutions of $1 \mathrm{~mol} / \mathrm{m}^{3}, 10^{-1}$ $\mathrm{mol} / \mathrm{m}^{3}, 10^{-2} \mathrm{~mol} / \mathrm{m}^{3}$ (Tab.3). The results shown in Tab.4. show that the development of hypocotyl at all tested $\mathrm{CdCl}_{2}$ concentrations have a strong toxic effect.

Based on the toxic effect on the root length and hypocotyl of the germ of barley (H.vulgare), Jadran variety, all tested metals can be compared in the series: $\mathrm{Cd}>\mathrm{Ni}>\mathrm{Pb}$.

Analyzing the variance of the two-factor trial and testing the significance of differences by LSD test for the P 0.05 and 0.01 risk level, we found that there were statistically significant to highly significant differences in root growth (Tab.3) and hypocotyl (Tab.4). The obtained results relate to all tested heavy metals and most of their concentrations compared with the control as well as for the interactions of heavy metals and concentrations.

Germination energy indicates seed quality. If the seeds germinate quickly and at a steady pace, better results are obtained in sowing, and the development of plant is more lush. It is actually a computerized method of utilizing data from the 
germination $\log$ in which are entered the type and variety of seeds, the date of placement of the sample, the number of germinated seeds per day and the number of germinated seeds at the end of the test (Komljenović \& Todorović, 1998).The smaller obtained number, the higher the seed germination energy, since more seeds germinated in shorter period of time.
Data on germination energy is important for practice because it indicates faster growth and independence of some cultivated plant species, which means that crops with higher germination energy will better resist the negative effects of initial growth.

Table 3. Root length (mm) of barley, Jadran variety, treated with heavy metal compounds $\mathrm{PbCl}_{2}, \mathrm{NiCl}_{2}, \mathrm{CdCl}_{2}$.

\begin{tabular}{|c|c|c|c|}
\hline $\begin{array}{c}\text { solution/ } \\
\text { concentration }\end{array}$ & $\begin{array}{c}\mathrm{PbCl}_{2} \\
(\min .-\max . \mathrm{mm})\end{array}$ & $\begin{array}{c}\mathrm{NiCl}_{2} \\
(\text { min.-max.mm) }\end{array}$ & $\begin{array}{c}C d C l_{2} \\
\text { (min.-max.mm) }\end{array}$ \\
\hline $10^{3} \mathrm{~mol} / \mathrm{m}^{3}$ & $\begin{array}{c}3.1 \\
(1-14)\end{array}$ & $\begin{array}{c}0 \\
(0-0)\end{array}$ & $\begin{array}{c}0 \\
(0-0)\end{array}$ \\
\hline $10^{2} \mathrm{~mol} / \mathrm{m}^{3}$ & $\begin{array}{c}5.6 \\
(1-26)\end{array}$ & $\begin{array}{c}2.3 \\
(1-5)\end{array}$ & $\begin{array}{c}1 \\
(0-1)\end{array}$ \\
\hline $10 \mathrm{~mol} / \mathrm{m}^{3}$ & $\begin{array}{c}43.2 \\
(2-77)\end{array}$ & $\begin{array}{c}7.9 \\
(1-30)\end{array}$ & $\begin{array}{c}3.4 \\
(1-69)\end{array}$ \\
\hline $1 \mathrm{~mol} / \mathrm{m}^{3}$ & $\begin{array}{c}45.3 \\
(1-67)\end{array}$ & $\begin{array}{c}38.6 \\
(3-110)\end{array}$ & $\begin{array}{c}21.2 \\
(2-132)\end{array}$ \\
\hline $10^{-1} \mathrm{~mol} / \mathrm{m}^{3}$ & $\begin{array}{c}53.2 \\
(11-85)\end{array}$ & $\begin{array}{c}54.9 \\
(2-112)\end{array}$ & $\begin{array}{c}35 \\
(1-108)\end{array}$ \\
\hline $10^{-2} \mathrm{~mol} / \mathrm{m}^{3}$ & $\begin{array}{c}54.2 \\
(25-100)\end{array}$ & $\begin{array}{c}66 \\
(4-107)\end{array}$ & $\begin{array}{c}47.9 \\
(1-115)\end{array}$ \\
\hline Control & $\begin{array}{c}76.3 \\
(19-135)\end{array}$ & $\begin{array}{c}76.3 \\
(19-135)\end{array}$ & $\begin{array}{c}76.3 \\
(19-135)\end{array}$ \\
\hline$L S D$ & $\begin{array}{l}\text { A-Concentratio of } \\
\text { heavy metals }\end{array}$ & $\begin{array}{c}B \text { - type of heavy } \\
\text { Metal }\end{array}$ & $A B$ \\
\hline 0,05 & 2.111 & 1.515 & 7.017 \\
\hline 0,01 & 3.140 & 2.233 & 10.510 \\
\hline
\end{tabular}

Table 4. Length of hypocotyl (mm) in barley of Jadran variety treated with heavy metal compounds $\mathrm{PbCl}_{2}, \mathrm{NiCl}_{2}, \mathrm{CdCl}_{2}$

\begin{tabular}{|c|c|c|c|}
\hline $\begin{array}{c}\text { solution/ } \\
\text { concentration }\end{array}$ & $\begin{array}{c}\mathrm{PbCl}_{2} \\
(\text { min.-max. mm) }\end{array}$ & $\begin{array}{c}\mathrm{NiCl}_{2} \\
(\text { min.-max. mm) }\end{array}$ & $\begin{array}{c}C d C l_{2} \\
(\min .-\max . \operatorname{mm})\end{array}$ \\
\hline $10^{3} \mathrm{~mol} / \mathrm{m}^{3}$ & $\begin{array}{c}2,3 \\
(1-15)\end{array}$ & $\begin{array}{c}0 \\
(0-0)\end{array}$ & $\begin{array}{c}0 \\
(0-0)\end{array}$ \\
\hline $10^{2} \mathrm{~mol} / \mathrm{m}^{3}$, & $\begin{array}{c}10.2 \\
(1-28)\end{array}$ & $\begin{array}{c}1.6 \\
(1-5)\end{array}$ & $\begin{array}{c}1 \\
(0-1)\end{array}$ \\
\hline $10 \mathrm{~mol} / \mathrm{m}^{3}$ & $\begin{array}{c}41.8 \\
(2-79)\end{array}$ & $\begin{array}{c}8.6 \\
(1-30)\end{array}$ & $\begin{array}{c}31.6 \\
(1-65)\end{array}$ \\
\hline $1 \mathrm{~mol} / \mathrm{m}^{3}$ & $\begin{array}{c}56.5 \\
(1-105)\end{array}$ & $\begin{array}{c}52.7 \\
(3-110)\end{array}$ & $\begin{array}{c}51.2 \\
(2-105)\end{array}$ \\
\hline $10^{-1} \mathrm{~mol} / \mathrm{m}^{3}$ & $\begin{array}{c}57.2 \\
(11-105)\end{array}$ & $\begin{array}{c}62.1 \\
(2-112)\end{array}$ & $\begin{array}{c}52.8 \\
(1-106)\end{array}$ \\
\hline $10^{-2} \mathrm{~mol} / \mathrm{m}^{3}$ & $\begin{array}{c}62 \\
(25-100)\end{array}$ & $\begin{array}{c}63.5 \\
(4-107)\end{array}$ & $\begin{array}{c}60.6 \\
(1-110)\end{array}$ \\
\hline Control & $\begin{array}{c}71.2 \\
(18-132) \\
\end{array}$ & $\begin{array}{c}71.2 \\
(18-132) \\
\end{array}$ & $\begin{array}{c}71.2 \\
(18-132) \\
\end{array}$ \\
\hline$L S D$ & $\begin{array}{c}A \text { Concentration of } \\
\text { heavy metals }\end{array}$ & $\begin{array}{l}B \text { type of heavy } \\
\text { metal }\end{array}$ & $A B$ \\
\hline \multirow{2}{*}{$\begin{array}{l}0,05 \\
0,01\end{array}$} & 1.277 & 1.459 & 4.812 \\
\hline & 2.462 & 2.690 & 5.440 \\
\hline
\end{tabular}


The results obtained for the germination energies of barley seeds in solutions of different concentrations of $\mathrm{PbCl}_{2}, \mathrm{NiCl}_{2}$, $\mathrm{CdCl}_{2}$ (Tab. 5) indicate that the tested solutions at all concentrations significantly reduce the energy of germination of barley seeds ( $H$. vulgare), Jadran variety. It is observed that germination energy decreases with increasing solution concentration.

Table 4. Comparative energy overview of the seed seeds in the solubility of various concentrations of $\mathrm{PbCl}_{2}, \mathrm{NiCl}_{2}, \mathrm{CdCl}_{2}$.

\begin{tabular}{|c|c|c|c|c|c|c|}
\hline & $10^{3} \mathrm{~mol} / \mathrm{m}^{3}$ & $10^{2} \mathrm{~mol} / \mathrm{m}^{3}$ & $10 \mathrm{~mol} / \mathrm{m}^{3}$ & $1 \mathrm{~mol} / \mathrm{m}^{3}$ & $10^{-1} \mathrm{~mol} / \mathrm{m}^{3}$ & $10^{-2} \mathrm{~mol} / \mathrm{m}^{3}$ \\
\hline $\mathbf{P b C l}_{\mathbf{2}}$ & 4.5 & 3.5 & 2.9 & 2.7 & 2.1 & 1.8 \\
\hline $\mathbf{N i C l}_{\mathbf{2}}$ & 0 & 3.9 & 3.1 & 3 & 2.3 & 1.9 \\
\hline $\mathbf{C d C l}_{\mathbf{2}}$ & 0 & 5 & 4.3 & 3.9 & 3 & 2 \\
\hline $\mathbf{H}_{\mathbf{2}} \mathbf{0}$ & 1.5 & & & & & \\
\hline
\end{tabular}

The germination energy in the control is 1.5 . In a solution of $\mathrm{NiCl}_{2}$, and $\mathrm{CdCl}_{2}$ at a concentration of $10^{-2} \mathrm{~mol} / \mathrm{m}^{3}$ is the smallest decrease in germination energy. $\mathrm{PbCl}_{2}$ solution has the weakest toxic effect compared to all tested metal. Seed germination occurred at all concentrations of this metal. However, the development of the germ shows that the lead has a toxic effect. A particularly good indicator of its toxicity is germination energy. In the solution of concentration $10^{-2} \mathrm{~mol} / \mathrm{m}^{3}$ germination energy is 1.8 . and this indicates that it takes longer for seeds to germinate than in control. The tested heavy metals at all concentrations showed a stronger toxic effect on germination energy than ongermination percentage.

Based on the toxic effect on the germination energy of barley seeds (H. vulgare), Jadran variety, the tested metals can be compared in the following order: $\mathrm{Cd}>\mathrm{Ni}>\mathrm{Pb}$.

In plants, these metals directly or indirectly cause a wide range of physiological and biochemical dysfunctions that lead to reduced yield (Amari et al., 2017). $\mathrm{Cd}, \mathrm{Pb}$, and $\mathrm{Ni}$ show phytotoxic effects on germination and germ development in Lactuca sativa, Brassica oleraceae, Lycopersicon esculeatum, Raphanus sativus (Johnson et al., 2011), Helianthus annus (Jadia \& Fulekar, 2008).

\section{CONCLUSION}

Based on the results obtained by testing different concentrations of $\mathrm{PbCl}_{2}, \mathrm{NiCl}_{2}, \mathrm{CdCl}_{2}$ solutions, on the percentage of germination, germination energy, root length and hypocotyl of the species (Hordeum vulgare L.), Jadran variety, it can be concluded that: barley seeds have significantly reduced germination in the presence of all tested heavy metals and germination length, root length and hypocotyl, as well as germination energy depend on the type of heavy metal and solution concentrations. The most toxic effect has $\mathrm{Cd}$ and the weakest toxic effect has $\mathrm{Pb}$.

\section{REFERENCES}

Ahmad, M. S., \& Ashraf, M. 2011. Essential roles and hazardous effects of nickel in plants. Rev Environ Contam Toxicol. 214, pp. 125-67. doi: 10.1007/978-1-4614-0668-6_6
Ahmadi, I., Javed Akthar, M., Zahir A. Z., \& Jamil, A. 2012. Effect of cadmium on seed germination and seedling growth of four wheat (Triticum aestivumL.) cultivars. Pak. J. Bot., 44(5), pp. 1569-1574.

Amari, T., Ghnaya, T., \& Abdelly, C. 2017. Nickel, cadmium and lead phytotoxicity and potential of halophyticplants in heavy metal extraction, South African Journal of Botany, 111, pp. 99-110. doi.org/10.1016/j.sajb.2017.03.011

Azmat, R., Haiderand, S., \& Askari S. 2006. Phytotoxicity of $\mathrm{Pb}$ : I Effect of $\mathrm{Pb}$ on Germination, Growth, Morphology and Histomorphology of Phaseolus mungo and Lens culinaris, Pakistan Journal of Biological Sciences, 9(5), pp. 979-984. doi: 10.3923/pjbs.2006.979.984

Chen, C., Huang, D., \& Liu, J. 2009. Functions and Toxicity of Nickel in Plants: Recent Advances and Future Prospects, Clean 37(4-5), pp. 304-313. doi.org/10.1002/clen.200800199

Djelic, G., Staletic, M., \& Milovanovic, M. 2012. Germination of oat (Avena sativa) seeds under heavy metal stress, Ecological movemetn of Novi Sad, Eco-conference 2012, pp. 251-259.

Djelic, G., Markovic, M., Brankovic, S., Brkovic, D., Vicentijevic-Markovic, G., \& Markovic, G. 2016. Efekat teških metala $(\mathrm{Cd}, \mathrm{Fe}, \mathrm{Ni}, \mathrm{Zn})$ na klijanje semena Robinia pseudoacacia L. Zbornik radova XXI Savetovanja obiotehnologiji sa međunarodnim učešćem, Čačak, 21(23), pp. 373-378.

Djelic, G., Novakovic, M., Brankovic, S., Timotijevic, S., \& Simic, Z. 2018. Comparative analysis of metal bioaccumulation et species Petroselinum crispum Mill, SeselirigidumW et K, Daucus carotaL., Conium maculatum L. Third Scientific Conference on Ecology, November $2^{\text {th }}-3^{\text {th }}$ 2018, Plovdiv, Program \& Abstracts, pp 57.http://web.uniplovdiv.bg/ecology/TACE2018/TASCE_2018_program_\&_b ook_of_abstracts.pdf.

Jadia, D. C., \& Fulekar, H. M. 2008. Phytoremediation: the application of vermicompost to remove zinc, cadmium, copper, nickel and lead by sunflower plant, Environmental Engineering and Management Journal, 7(5), pp. 547-558. doi: 10.30638/eemj.2008.078

Jiang, W., Liu, D., \& Hou, W. 2001. Hyperaccumulation of cadmium by roots, bulbs and shoots of garlic. Biores. Technol., 76, pp. 9-13. doi: 10.1016/s0960-8524(00)00086-9

Johnson, A., Singhal, N., \& Hashmatt M. 2011. Metal-plant Interactions: Toxicity and Tolerance in: Khan, SM, Zaidi, A., Goel, R., Musarrat J., (eds): Biomanagement of MetalContaminated Soils, Springer Dordrecht Heidelberg London New York, pp. 29-67. 
Kabata-Pendias, A. 2011.Trace elements in soils and plants, 4th ed. CRC Press, Taylor\&Francis Group, Boca Raton London New York Washington, D.C.

Kenedy, S. P., Bingham, I. J., \& Spink, J. H. 2017. Determinants of spring barley yield in a high-yieldpotential environment, The Journal of Agricultural Science, 155(1), pp. 60-80. doi.org/10.1017/S0021859616000289

Khan, N. A., Ahmad, I., Singh, S., \& Nazar, R.. 2006. Variation in growth, photosynthesis and yield of five wheat cultivars exposed to cadmium stress. World J. Agri. Sci., 2, pp. 223226.

Komljenovic, I., \& Todorovic, V. 1998. Opsteratarstvo-udzbenik Poljoprivredni fakultet. Banja Luka.

Kricka, T., Kis, D., Matin, A., Brlek, T., \& Bilandžija, N. 2012. Tehnologija mlinarstva, Poljoprivredni fakultet u Osijeku, Agronomski fakultet u Zagrebu.

Leone,V., Rabier, J., Notonier, R., Barthelemy, R., Moreau, X., Bouraima-Madjebi, S., Viano, J., \& Pineau, R. 2005. Effects of Three Nickel Salts on Germinating Seeds of Grevilleaexul var. rubiginosa, an Endemic Serpentine Proteaceae, Ann Bot. 95(4), pp. 609-618. doi:10.1093/aob/mci066

Madic, M., Knezevic, D., \& Paunovic, A. 2011. Osnovni parametri u oplemenjivanju jecma (Hordeum vulgare L.) naprinos I kvalitet. u: Medjunarodni naučni simpozijum agronoma AGROSYM Jahorina, 2011, Republika Srpska, Zbornik radova, pp. 276-286.

Peralta-Videa, J. R,. Gardea-Torresdey, J. L, Gomez, E., Tiermann, K. J., Parsons, J. G., \& Carrillo, G.. 2002. Effect of mixed cadmium, copper, nickel and zinc at different $\mathrm{pHs}$ upon alfalfa growth and heavy metal uptake. Environ. Pollut., 119, pp. 291-301. doi: 10.1016/s0269-7491(02)00105-7

Pesko, M., Králová, K., \& Masarovicová, E. 2011. Phytotoxic effect of same metal ions on selected raspeseed cultivars registered in Slovakia. Proceedings of ECOpole, 5(1), pp. 83 86.

Poehlman, J. M. 1985. Adaptation and distribution. In: Rasmusson DC, editor. Barley. Madison, Wisconsin: American Society of Agronomy, Inc., Crop Science Society of America, Inc., Soil Science Society of America, Inc. pp. 117. doi.org/10.5772/intechopen.68359

Polacco J. C., Mazzafera P., \& Tezotto T. 2013. Opinion: nickel and urease in plants: still many knowledge gaps. Plant Sci. 199-200, pp. 79-90. doi: 10.1016/j.plantsci.2012.10.010
Porebska, G., \& Ostrowska. A. 1999. Heavy Metal Accumulation in Wild Plants: Implications for Phytoremediation, Polish Journal of Environmental Studies, 8(6), pp. 433-442.

Rajkovic, M., Stojanovic, M., Glamoclija, Dj., Toskovic, D., Miletic, V., Stefanovic, V., \& Lacnjevac, C. 2012. Pšenica i teškimetali, Journal of Engineering \& Processing Management, 4(1), pp. 85-125 doi:10.7251/JEPM1204085R

Salamini, F., Özkan, H., Brandolini, A., Schäfer-Pregl, R., \& Martin, W. 2002. Genetics and geography of wild cereal domestication in the near east. Nature Reviews Genetics. 3(6), pp. 429-441. doi: 10.1038/nrg817

Shafi, M., Zhang, G.. P.,Bakht, J., Khan, M. A. ,Islam, E., Dawood, M. K., \& Raziuddin, I. 2010. Effect of cadmium and salinity stresses on root morphology of wheat. Pak. J. Bot., 42(4), pp. 2747-2754.

SPSS Inc. Systat 10.0 Statistics I software. Chicago; 2000. p. 663.

Stankovic, M., Markovic, A., Pavlovic, D., Topuzovic, M., Djelic, G., Bojovic, B., \& Brankovic, S. 2010. Toksicni efekat kadmijuma (Cd) na klijanje semena psenice (Triticum aestivum L.). Zbornik radova sa XV Savetovanja o biotehnologiji. 15(17), pp. 975-980.

Steiger B. V., Webster, R., Schulin, R., \& Lehmann, R. 1996. Mapping heavy metals in polluted soil by disjunctive kriging. Environ. Pollut., 94, pp. 205-215. doi:10.1016/s02697491(96)00060-7

Zhang J, Zheng H. G., Aarti, A., Pantuwan,G,, Nguyen, T. T., Tripathy, J. N., Sarial, A. K., Robin, S., Babu, R. C., Nguyen, B. D., Sarkarung, S., Blum, A., \& Nguyen, H. T. 2001. Location genomic regions Barley (Hordeum vulgare L.) Improvement Past, Present and Future associated with components of drought resistance in rice: Comparative mapping within and across species. Theoretical and Applied Genetics, 103, pp. 19-29. doi.org/10.5772/intechopen.68359 63

Tanner, G. J, Blundell, M. J, Colgrave, M. L., \& Howitt, C. A. 2016. Creation of the first ultra-low gluten barley (Hordeum vulgare L.) for coeliac and gluten-intolerant populations, Plant Biotechnol J. 14(4), pp. 1139-1150. doi: 10.1111/pbi.12482 